\title{
Expression of the 5T4 oncofoetal antigen in renal cell carcinoma: a potential target for T-cell-based immunotherapy
}

\author{
RW Griffiths', DE Gilham', A Dangoor', V Ramani ${ }^{3}$, NW Clarke ${ }^{3}$, PL Stern ${ }^{2}$ and RE Hawkins*,I \\ 'Department of Medical Oncology, Paterson Institute for Cancer Research, Christie Research Centre, Manchester M20 4BX, UK; ${ }^{2}$ Department of \\ Immunology, Paterson Institute for Cancer Research, Manchester M20 4BX, UK; ${ }^{3}$ Department of Urological Surgery, Christie Hospital NHS Trust, \\ Manchester M20 4BX, UK
}

The 5T4 oncofoetal antigen is a heavily glycosylated cell surface protein found on human placental trophoblast and on diverse types of human cancer but is not expressed at significant levels on adult human tissues in health. It therefore satisfies the criteria for a tumour-associated antigen and is an ideal target for the immunotherapy of cancer. We report here that 5 T4 is strongly expressed on the majority of renal cell carcinomas and therefore this population of patients is suitable for trials of 5T4-targeted therapies. In particular, we have shown that $\mathrm{T}$ cells from renal cell carcinoma patients can be genetically modified to kill 5T4 expressing renal cancer cell lines by introduction of a chimeric-signalling protein. This protein consists of a single chain antibody fragment capable of binding antigen directly at the cell surface and then activating the T cell by virtue of a CD3ל-signalling domain. This is a powerful tool that bypasses a number of mechanisms that allow tumours to escape T-cell killing and can be readily scaled up for clinical use. British Journal of Cancer (2005) 93, 670-677. doi:I0.1038/sj.bjc.6602776 www.bjcancer.com Published online 13 September 2005 (c) 2005 Cancer Research UK

Keywords: renal cell carcinoma; immunotherapy; 5T4; oncofoetal antigen

Renal cell carcinoma (RCC) makes up around 3\% of all adult malignant tumours in the United Kingdom and is the commonest neoplasm arising from the kidney (Cancer Registration Statistics, 2001). Approximately a third of patients are cured by surgery while treatment options for metastatic disease are very limited, as the cancer tends to be resistant to both chemotherapy and radiotherapy. Median survival for patients with untreated metastatic disease is around 12 months (Atzpodien et al, 2003). The only drugs proven to induce regression of the disease are the immunomodulatory agents interferon- $\alpha$ (MRC Renal Cancer Collaborators, 1999) and interleukin-2 (IL-2) (Yang et al, 2003). Response rates with these agents are low, in the order of $14-20 \%$ and, although a survival advantage has been demonstrated for interferon- $\alpha$ over hormonal therapy alone, no clear survival advantage has been demonstrated for IL-2.

Central to the development of better biological therapy for RCC is the need to identify aberrant or overexpressed proteins that may distinguish the tumour from normal tissues. These proteins can then be targeted by a variety of therapeutic strategies such as monoclonal antibodies (Mab), vaccines or adoptive transfer of antigen specific $\mathrm{T}$ cells. The goal of these approaches is that the tumour is recognised by the immune system and then eliminated by cytotoxic effector cells. To date only a small number of aberrantly expressed proteins have been associated with RCC. Some of these, such as G250, are cell surface proteins that have

*Correspondence: Professor RE Hawkins;

E-mail: rhawkins@manchester.ac.uk

Revised 4 May 2005; accepted 9 August 2005; published online 13 September 2005 been identified by murine Mab (Oosterwijk et al, 1986). Clinical trials are already underway utilising a number of immunotherapeutic modalities targeting the G250 protein in RCC (Lamers et al, 2002; Bleumer et al, 2004).

A number of oncofoetal antigens have now been identified that are expressed in foetal tissues and also by certain malignancies. $5 \mathrm{~T} 4$ is a $72 \mathrm{kDa}$ glycoprotein identified by a murine monoclonal antibody produced by a hybridoma from splenocytes of mice immunised with syncytiotrophoblast microvillous membrane glycoproteins (Hole and Stern, 1988). It is highly expressed on placental trophoblast and a variety of human cancers (Southall et al, 1990). Transduction of the 5T4 cDNA into cell lines enhances cell motility and reduces cell-cell contacts suggesting that it may be mechanistically involved in the malignant phenotype (Carsberg et al, 1996). This is further supported by evidence that expression of 5T4 correlates with poorer survival in colorectal carcinoma (Starzynska et al, 1994). This protein has only limited expression in normal adult human tissues (Southall et al, 1990) making it a useful target for the immunotherapy of cancer.

The most successful targeted approach to immunotherapy undoubtedly has been the use of monoclonal antibody therapy, notably in breast cancer (trastuzumab) (Cobleigh et al, 1999) and non-Hodgkin's lymphoma (rituximab) (Czuczman et al, 2005). Once bound to their respective target, Mab's induce antitumour activity by one of three principle mechanisms: antibody-dependent cell-mediated cytotoxicity (Clynes et al, 2000), interruption of aberrant cell-signalling proteins (Le et al, 2000) or delivery of a cytotoxic moiety such as a drug, radioisotope or toxin to the tumour (Wiseman et al, 2002). Antibody therapy does, however, have a number of limitations such as poor penetration into 
tumour, selection of apoptosis-resistant tumour clones and inactivation of Mab by serum proteins (Reilly et al, 1995; Jain, 1999). Other strategies for generating an effective immune response against solid tumours such as vaccination and adoptive transfer of antigen-specific $\mathrm{T}$ cells are therefore being actively developed.

$\mathrm{T}$ cells are one of the key effector cells in a host response to a tumour (Finn and Lotze, 2001), but by the time a cancer has become established, it may have evolved strategies to evade T-cell killing. These include the downregulation of major histocompatibilty complex (MHC) molecules and associated transporter proteins thus preventing antigen presentation of endogenous peptides (Garrido et al, 1997) and induction of tolerance in T cells with specificity for tumour-borne epitopes (Mapara and Sykes, 2004). Nevertheless, tumour antigen-specific lymphocytes have been isolated from tumour-infiltrating lymphocytes (TILs) of malignant melanoma (Dudley et al, 2002) and these cells were able to reject tumour upon reinfusion following lymphodepleting chemotherapy. It has proved much harder to isolate such cells from RCC tumours (Yannelli et al, 1996) and the few studies using adoptive cell transfer are yet to yield any encouraging results (Goedegebuure et al, 1995; Figlin et al, 1999; Dillman et al, 2004).

It may therefore be desirable to evaluate other methods of making $\mathrm{T}$ cells that can recognise renal cell cancer. $\mathrm{T}$ cells can be genetically modified in vitro to possess Mab specificity for a protein epitope by retroviral transduction with a chimeric T-cell receptor (Thistlethwaite et al, 2005). This circumvents the natural process of T-cell activation through MHC and means that a large polyclonal pool of $\mathrm{T}$ cells can be conferred with specificity for one single antigen. We have previously demonstrated that $\mathrm{T}$ cells from patients with colorectal cancer can kill CEA-expressing cell lines when retrovirally transduced with a chimeric T-cell receptor with specificity for CEA protein (Sheen et al, 2003). The chimeric T-cell receptor consists of an extracellular recognition domain comprising a single chain antibody fragment; this is then fused to an intracellular $\mathrm{CD} 3 \zeta$-signalling domain found in the wild-type TCR. Crosslinking of the chimeric TCR with its respective antigen results in downstream activation of the $\mathrm{T}$ cell, which is then able to effect target cell killing either directly by production of cytotoxic moieties such as granzyme, perforin and Fas ligand, or indirectly via production of cytokines important for T-cell killing such as interferon- $\gamma$ (Darcy et al, 2000).

Our first aim in this study was to evaluate the expression of the 5T4 oncofoetal antigen by immunohistochemistry in freshly isolated RCC specimens. Secondly, we wished to test its utility as a target for gene modified $\mathrm{T}$ cells taken from patients with RCC. Using a chimeric T-cell receptor that binds to the 5T4 protein we have evaluated whether $\mathrm{T}$ cells from patients with RCC could be genetically modified to kill allogeneic 5T4-expressing renal cell lines.

\section{MATERIALS AND METHODS}

All tissue and blood samples were collected from three hospitals in the South Manchester region. Approval from the local ethical committee was given prior to sample collection and informed consent was obtained from each patient at least a day before surgery. Additionally, five frozen specimens of normal kidney from donors without malignant disease were obtained from a biomaterials supplier (Medical Solutions, Nottingham, UK). Specimens were obtained post mortem with donor consent and ethical approval.

\section{Immunohistochemistry}

Tumour samples were taken from either primary or metastatic disease in patients with RCC (either suspected or confirmed).
Where possible samples of kidney (at a distance of at least $2 \mathrm{~cm}$ away from the primary tumour) were also taken and termed 'normal' for this study. The histological type and grade of tumour was assessed by routine haematoxylin and eosin staining of paraffin-embedded sections.

Tumour and kidney samples were snap frozen and sectioned using a freezing microtome. A three-stage immunoperoxidase technique using the EnVision kit (DakoCytomation Ltd, Denmark) was used to visualise the 5T4 glycoprotein. Immunohistochemical staining was performed according to the manufacturer's instructions. A murine monoclonal antibody specific for 5T4 was used as a primary antibody (5T4 $\mathrm{IgG}_{1} 2.2 \mathrm{mg} \mathrm{m}^{-1}$ ) at a 1 in 1000 dilution. Production and characterisation of this antibody has previously been described (Hole and Stern, 1988). A murine $\mathrm{IgG}_{1}$ isotype control was applied at the same concentration to separate sections to act as a negative control.

\section{Cell culture}

The renal carcinoma cell lines were a kind gift from Dr J Yang of the National Institutes of Health, Bethesda, MD, USA. They were cultured as an adherent monolayer in Dulbecco's Modified Eagle Medium with $10 \%$ foetal calf serum (Gibco BRL, Paisley, Scotland). $\mathrm{T}$ cells were cultured in T-cell media consisting of RPMI-1640 supplemented with $25 \mathrm{mmoll}^{-1}$ HEPES, $50 \mu \mathrm{moll}^{-1} \beta$ mercaptoethanol, $200 \mathrm{mmoll}^{-1} \mathrm{~L}$-glutamine, $50 \mathrm{IU} \mathrm{ml}^{-1}$ penicillin, $50 \mu \mathrm{g} \mathrm{ml}^{-1}$ streptomycin (all from Sigma, Dorset, UK) and 5\% human AB serum (Promocell, Heidelberg, Germany). Cells were kept at $37^{\circ} \mathrm{C}$ in a humidified atmosphere containing $95 \%$ air and $5 \% \mathrm{CO}_{2}$.

\section{Isolation and activation of peripheral blood lymphocytes}

In all, $50 \mathrm{ml}$ of heparinised blood was taken from patients at the time of surgery. The mononuclear cell fraction was isolated by Ficoll-Hypaque (PAA Laboratories, Pasching, Austria) density centrifugation. The cells were washed twice in RPMI-1640 and resuspended in $\mathrm{T}$-cell media before depletion of monocytes by plastic adherence. After $1 \mathrm{~h}$ the flask was removed and nonadherent cells were removed and resuspended in T-cell medium supplemented with $100 \mathrm{IU} \mathrm{ml}^{-1}$ of recombinant human IL-2 (Chiron, Amsterdam, The Netherlands) at a concentration of $1 \times 10^{6} \mathrm{cells} \mathrm{ml}^{-1}$ in T-cell media. The cells were then incubated for 3 days in six-well tissue culture plates precoated with anti-CD3 (Orthoclone, NJ, USA) and anti-CD28 (R\&D Systems, MN, USA) Mab. Lymphocytes were then maintained in culture by adding IL-2 every $3-4$ days and maintaining cell concentration around $1 \times 10^{6}$ cells.

\section{Retroviral transduction of peripheral blood lymphocytes}

The Kat retroviral system (Finer et al, 1994) was used to genetically modify the isolated lymphocytes by introducing DNA coding for one of two chimeric T-cell receptors. The retroviral vector

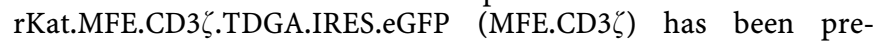
viously described (Gilham et al, 2002) and encodes a chimeric Tcell receptor specific for CEA. To create a chimeric T-cell receptor specific for the $5 \mathrm{~T} 4$ protein, DNA coding for a humanised $\mathrm{scFv}$ derived from the mouse anti-human 5T4 monoclonal antibody, together with a human Fc antibody spacer region was exchanged into the above vector. The inclusion of the Fc space was found to be optimal for targeting gastrointestinal cancers expressing 5T4 (Guest et al, 2005) and was used in this analysis. This construct 5T4.hFc.CD3 $\zeta . T D G A . I R E S . e G F P$ was abbreviated to 5T4.CD3 $\zeta$. Transduced lymphocytes coexpressed enhanced green fluorescent protein to allow identification of this population by flow cytometry. 
The rKat vector was combined with the packaging plasmid pKat and introduced into the $293 \mathrm{~T}$ packaging cell line by calcium phosphate transfection. Virus was harvested at 48 and $72 \mathrm{~h}$. The first viral harvest was timed to coincide with the end of the 3-day activation period of lymphocytes as described above. Lymphocytes and viral particles were combined in T-cell medium supplemented with $4 \mu \mathrm{g} \mathrm{ml}^{-1}$ polybrene and then centrifuged at $1200 \times \mathrm{g}$ for $3 \mathrm{~h}$. This spin-fection was then repeated the following day after the second viral harvest.

\section{Flow cytometry}

Surface markers of in vitro cultured cells was analysed on a FACScan (Becton Dickinson, CA, USA) and analysed using CellQuest software. Cells $\left(2 \times 10^{5}\right)$ were resuspended in phosphate-buffered saline supplemented with $2 \%$ bovine serum albumin. Phyco-erythrin-conjugated antibodies were used to stain for CD3, CD4 and CD8 (all from Becton Dickinson). 5T4 staining was performed using $1 \mu \mathrm{g} \mathrm{ml}^{-1}$ of murine anti-5T4 followed by phyco-erythrin-conjugated anti-mouse IgG (Sigma, Dorset, UK).

\section{Chromium release assay}

To measure short-term cytotoxicity mediated by $\mathrm{T}$ cells a standard 4-h chromium release assay was used. Target cells were incubated for $1 \mathrm{~h}$ with $100 \mu \mathrm{Ci}\left[{ }^{51} \mathrm{Cr}\right]$ sodium chromate, washed three times in serum-free media before resuspending in T-cell media at a concentration of $5 \times 10^{4}$ cells ml ${ }^{-1}$. A total of 5000 target cells per well were then plated out with effector cells in triplicates at the following ratios: $50: 1,25: 1,12.5: 1$ and $6.25: 1$. Spontaneous release was quantified by adding $\mathrm{T}$-cell medium alone to targets and maximal release by adding $2 \%$ Triton to targets. Following $4-\mathrm{h}$ coculture, supernatants were removed and plated on to Luma plates (Packard, Berkshire, UK), released radioactivity was measured using a TopCount plate reader Packard, Berkshire, UK). Percentage-specific lysis of targets was calculated using the following formula: (maximal release-sample release)/(maximal release-spontaneous release) $\times 100$.

\section{interferon- $\gamma$ release by enzyme-linked immunosorbent assay}

Triplicate wells consisting of $1 \times 10^{4}$ RCC cells and $1 \times 10^{5}$ lymphocytes per well in T-cell medium were set up on a 96-well plate. The cocultures were left for $24 \mathrm{~h}$ in an incubator at $37^{\circ} \mathrm{C}$ supplemented with $5 \% \mathrm{CO}_{2}$. The supernatants were removed and interferon- $\gamma$ concentration determined using matched antibody pairs MAB285 and BAF285 following the protocol defined in the manufacturer's instructions ( $\& \mathrm{D}$, Oxfordshire, UK).

\section{RESULTS}

\section{T4 expression on RCC biopsies}

Using the EnVision kit, a dark brown precipitate was observed on the specimen if 5T4 was present. Two observers independently examined the specimens under light microscopy and classified them into one of these four groups: strongly positive $(++)$, positive $(+)$, focal staining $(+/-)$ or negative $(-)$ if no staining was observed. The pattern of staining was also characterised as either stromal, tumour membranous or tumour cytoplasmic. This categorisation was used based on the previous patterns of staining noted in colorectal and gastric carcinomas (Starzynska et al, 1994). All positive samples however, clearly demonstrated a membranous staining pattern (Figure 1A) and there was no evidence of stromal staining on any of the tumour specimens. Tumour samples were obtained from 20 patients; 18/20 were primary clear cell carcinomas (Table 1), the remaining two being papillary cell
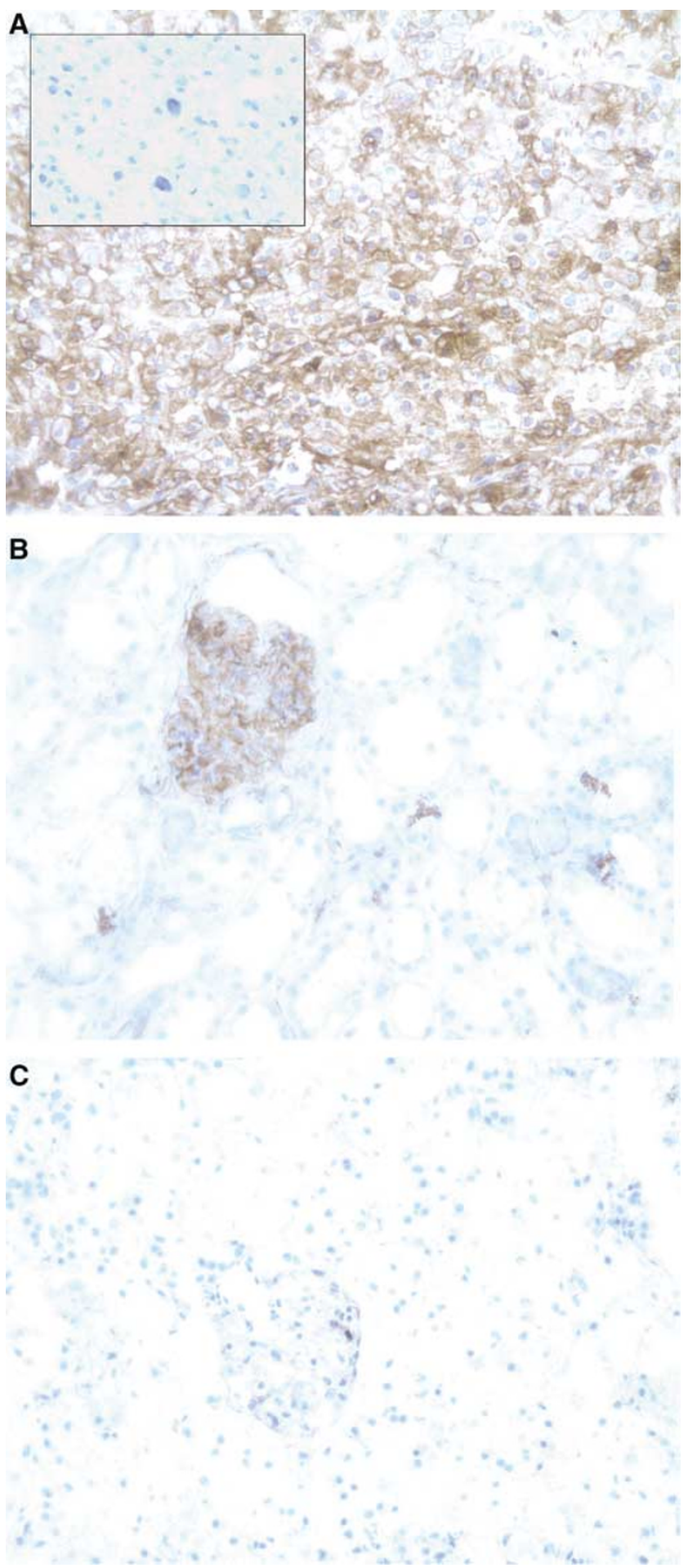

Figure I Strong positive 5T4 expression in renal cell carcinoma. Light microscopy ( $\times 20$ magnification) of a Fuhrman grade 3 clear cell carcinoma (A) following application of murine anti-human 5T4 followed by immunoperoxidase (brown precipitate denoting presence of bound murine antibody) and haematoxylin stains. The inset picture shows the same tissue with a mouse isotype control antibody applied. All malignant tissue examined that stained positive for 5T4 exhibited a membranous staining pattern. A section of kidney taken from the same patient is demonstrated (B) showing brown staining within a swollen glomerulus. A sample of tissue from a normal kidney taken from a donor with nonmalignant disease $(\mathbf{C})$ was also obtained and this shows much weaker stromal staining within the glomerulus. 
Table I Patient characteristics and 5T4 expression

\begin{tabular}{|c|c|c|c|c|c|c|}
\hline Sex & Age & Nature of specimen & Histology & Fuhrman grade & TNM stage & Pattern of $5 \mathrm{~T} 4$ staining \\
\hline $\mathrm{F}$ & 67 & Primary renal & Papillary & 2 & T2NOMO & ++ \\
\hline M & 67 & Primary renal & Papillary & 2 & TIbNOMO & ++ \\
\hline$M$ & 70 & Primary renal & Clear cell & 2 & T3aNOMO & $+1-$ \\
\hline $\mathrm{F}$ & 53 & Primary renal & Clear cell & 3 & T3aNOMO & - \\
\hline $\mathrm{F}$ & 67 & Primary renal & Clear cell & 3 & T3aNOMO & ++ \\
\hline F & 48 & Primary renal & Clear cell & 2 & TIaNOMO & + \\
\hline $\mathrm{F}$ & 68 & Primary renal & Clear cell & 2 & TIbNOMO & ++ \\
\hline$M$ & 57 & Primary renal & Clear cell & 4 & T4N2MI & ++ \\
\hline$M$ & 73 & Primary renal & Clear cell & 2 & TIbNOMO & ++ \\
\hline$M$ & 50 & Primary renal & Clear cell & I & TIbNOMO & ++ \\
\hline$M$ & 49 & Primary renal & Clear cell & 4 & T3bNOMO & + \\
\hline$M$ & 75 & Primary renal & Clear cell & 3 & T3bNOMO & $+1-$ \\
\hline M & 64 & Primary renal & Clear cell & 2 & T3bNOMO & ++ \\
\hline $\mathrm{F}$ & 46 & Primary renal & Clear cell & 2 & T3aNOMO & ++ \\
\hline $\mathrm{F}$ & 65 & Primary renal & Clear cell & 3 & T3bNOMO & ++ \\
\hline$M$ & 64 & Primary renal & Clear cell & 2 & T3bNOMO & ++ \\
\hline $\mathrm{F}$ & 43 & Metastasis & Clear cell & NA & TXNXMI & ++ \\
\hline$M$ & 66 & Metastasis & Clear cell & NA & TXNXMI & ++ \\
\hline$M$ & 49 & Primary renal & Clear cell & 3 & TIaNOMO & ++ \\
\hline $\mathrm{F}$ & 51 & Primary renal & Clear cell & 2 & T3aNOMO & ++ \\
\hline
\end{tabular}

$\mathrm{NA}=$ not applicable.

carcinomas. 19/20 (95\%) samples were at least focally positive for 5T4 and 15/20 (75\%) exhibited strong positive staining. From five patients, samples of 'normal' kidney at least $2 \mathrm{~cm}$ from the resection margin were taken at nephrectomy. Four of the five samples demonstrated strong positive glomerular staining (Figure 1B) while the remaining sample exhibited some focal tubular staining. However, haematoxylin and eosin staining showed an inflammatory infiltrate in all of these specimens and glomerulosclerosis was present in two. The possibility that antigen shedding from the tumour with subsequent deposition in the Bowman's capsule prompted us to evaluate specimens from donors without malignant disease. We examined five samples of normal kidney taken from post mortem specimens. All five demonstrated a weak focal glomerular staining and this was notably less than that seen in the RCC patient 'normal' kidney.

\section{T4 expression on RCC lines}

The renal cell lines 2220R, 2245R, 2246R where trypsinised and washed twice in serum-free DMEM. 5T4 expression was evaluated by applying the murine antibody or isotype control and then a secondary phycoerythrin-labelled anti-mouse IgG antibody. All cell lines demonstrated clear expression of 5T4 (Figure 2).

5T4.CD3 $\zeta$ transduced lymphocytes demonstrate enhanced killing and interferon $-\gamma$ release when in contact with renal cell lines

Peripheral blood lymphocytes from three patients with RCC were activated on anti-CD3/anti-CD28-coated tissue culture plates as described above. For each patient, a third of the activated $\mathrm{T}$ cells underwent a mock transduction with no retrovirus; this population would be used as a negative control to determine background levels of cytotoxicity and cytokine release. A third of the activated lymphocytes were transduced with the MFE.CD3 $\zeta$ construct and the remaining third transduced with the 5T4.CD3 $\zeta$ construct. The RCC cell lines did not express CEA (data not shown) and therefore the purpose of using $\mathrm{T}$ cells transduced with the MFE.CD3 $\zeta$ construct was to demonstrate that killing and cytokine release was dependent on the specificity of the $5 \mathrm{~T} 4 . \mathrm{CD} 3 \zeta$ chimeric receptor. We have previously shown the specificity of this receptor for human 5T4 expressed in mouse cell lines (Guest et al, 2005). At 3
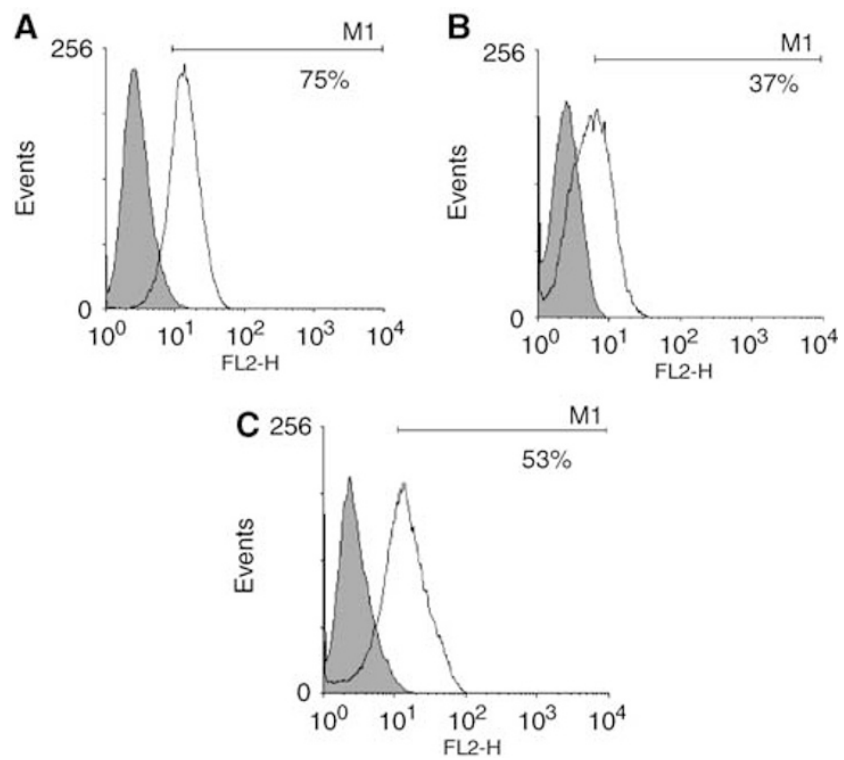

Figure $25 T 4$ expression in renal cell carcinoma lines. Renal cell carcinoma cell lines were incubated with murine anti-5T4 antibody or isotype control and then a secondary PE-labelled anti mouse IgG applied. The histograms show the FACS results for $(\mathbf{A}) 2220 \mathrm{R},(\mathbf{B}) 2245 \mathrm{R}$ and $(\mathbf{C})$ 2246R.

days prior to performing any of these assays, the IL-2 concentration in the T-cell cultures was reduced to $20 \mathrm{IU} \mathrm{ml}^{-1}$ to reduce any background lymphocyte-activated killer (LAK) activity. All assays were performed within 3 weeks of initial transduction.

Prior to each assay being performed, the lymphocyte populations were analysed by flow cytometry. All lymphocyte populations were $>92 \% \mathrm{CD} 3+$ ve indicating they were predominantly $\mathrm{T}$ cells (Table 2). In patients 4,11 and 14 the transduction levels of MFE.CD3 $\zeta$ were 43,38 and $24 \%$, respectively. However, the values for $5 \mathrm{~T} 4 . \mathrm{CD} 3 \zeta$ were significantly lower for each patient at 22,15 and $13 \%$, respectively (Table 2 ). We have routinely found that efficiency of expression of the 5T4.CD3 $\zeta$ construct is approximately half the level of the MFE.CD3 $\zeta$ construct although the 
reason for this is not clear. A $4 \mathrm{~h}$ chromium release assay was performed on each of the three RCC lines and in each case, we observed significantly enhanced killing of the renal cell lines by 5T4.CD3 $\zeta$-transduced lymphocytes when compared to either the MFE.CD3 $\zeta$ transduced or the mock-transduced lymphocytes (Figure 3). To determine functionality of the modified $\mathrm{T}$ cells in mounting an effective cytokine response, the production of interferon- $\gamma$ from $T$ cells was assayed when cocultured with target cells at a ratio of $10: 1$. Figure 4 demonstrates that the 5T4.CD3 $\zeta$ transduced $\mathrm{T}$ cells were able to generate significantly higher amounts of interferon- $\gamma$ on contact with 5T4 expressing cell lines compared to either mock transduced or MFE.CD3 $\zeta$-transduced $\mathrm{T}$ cells. Importantly, the levels of cytotoxicity and interferon- $\gamma$ release in the mock and MFE.CD3 $\zeta$-transduced cells were similar

Table 2 Phenotype of transduced lymphocytes

\begin{tabular}{|c|c|c|c|c|}
\hline & CD3 (\%) & CD4 (\%) & CD8 (\%) & EGFP (\%) \\
\hline \multicolumn{5}{|l|}{ Patient 4} \\
\hline Mock & 94 & 50 & 36 & NA \\
\hline MFE.CD3 & 95 & 50 & 35 & 43 \\
\hline 5T4.CD3 & 92 & 40 & 36 & 22 \\
\hline \multicolumn{5}{|l|}{ Patient II } \\
\hline Mock & 98 & 35 & 60 & NA \\
\hline MFE.CD3 & 99 & 31 & 57 & 38 \\
\hline 5T4.CD3 & 99 & 35 & 58 & 15 \\
\hline \multicolumn{5}{|l|}{ Patient 14} \\
\hline Mock & 94 & 15 & 68 & NA \\
\hline MFE.CD3 & 96 & 18 & 64 & 24 \\
\hline $5 T 4 . C D 3 \zeta$ & 95 & 22 & 65 & 13 \\
\hline
\end{tabular}

NA $=$ not applicable. indicating that this effect had not occurred as a result of retroviral transduction.

\section{DISCUSSION}

We have demonstrated in twenty RCC specimens that the 5T4 oncofoetal antigen is expressed to high levels in almost all cases of RCC. Importantly, the strong positive membrane expression on most of the tumour specimens makes RCC a good candidate for 5T4-targeted therapies. Previous reports of 5T4 have documented minimal expression on normal tissue (Southall et al, 1990) and we wished to confirm this was the case with respect to the kidney. We were able to analyse normal kidney taken greater than $2 \mathrm{~cm}$ from the tumour margin in five patients, however, the surrounding

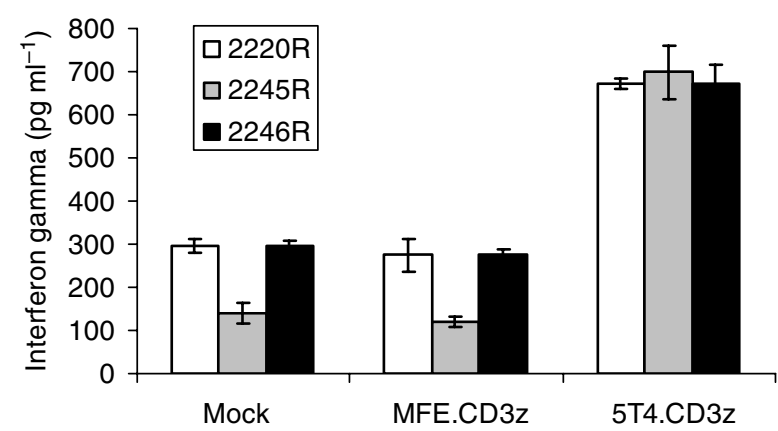

Figure 4 Interferon- $\gamma$ release. Representative results again from patient 4. In all, I $\times 10^{5}$ lymphocytes were cocultured for $24 \mathrm{~h}$ with $\mathrm{I} \times 10^{4} \mathrm{RCC}$ cells from the three cell lines: 2220R, 2245R and 2246R. After 24h the supernatants were removed and assayed for interferon- $\gamma$ by ELISA. Error bars refer to the s.d. for each dilution.
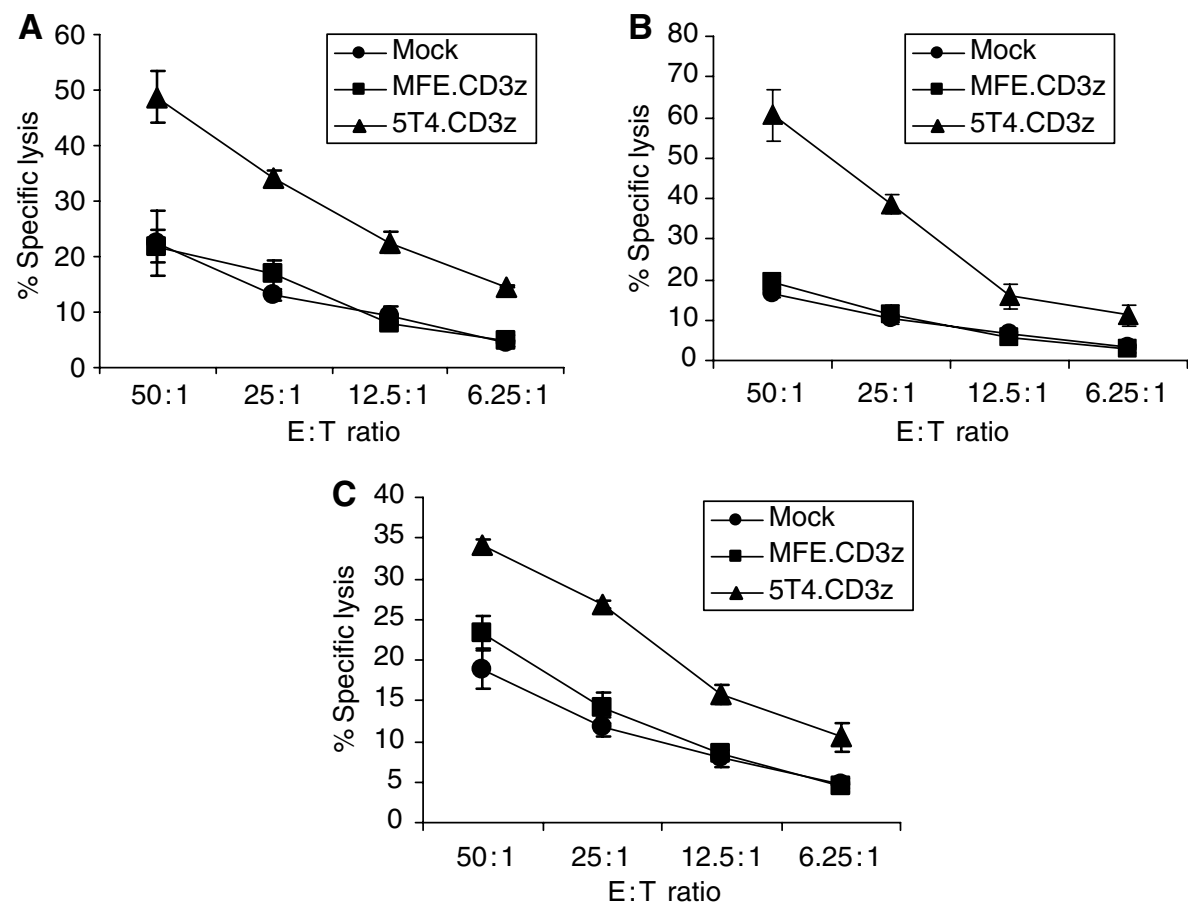

Figure 35 T 4 targeted T cells efficiently kill 5T4 expressing RCC lines. Lymphocytes from patient 4 were activated, expanded and transduced with either

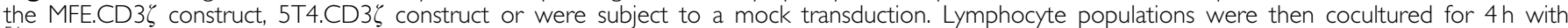
${ }^{51}$ Cr-labelled RCC cells from cell lines (A) 2220R, (B) 2245R and (C) 2246R. Each point represents a triplicate of wells, each well containing 5000 target tumour cells. The bars refer to the s.d. for each dilution. 
kidney in RCC frequently shows inflammatory change and our samples were no exception. We observed the presence of 5T4 within the Bowman's capsule in all five of our 'normal' kidney specimens. In case this result was due to antigen shedding and glomerular deposition, we also examined five post mortem specimens from donors who had otherwise healthy kidneys and no known malignant disease. They also showed some evidence of focal glomerular 5T4 expression although to a much lesser extent. It would appear therefore; that there is low-level expression of 5T4 on renal glomeruli and this confirms a previously published result (Connolly et al, 2003; Valle et al, 2003). A number of immunological therapies targeting 5T4 are currently undergoing assessment in phase I and II clinical trials and it should be noted that in no patients to date has any renal toxicity been reported. 5T4 has been targeted by a vaccine-based approach: A gene-modified vaccine has been developed by inserting the gene for $5 \mathrm{~T} 4$ into an attenuated vaccinia virus (Trovax ${ }^{\mathrm{TM}}$ ). In preclinical murine models a similar construct demonstrated protection against tumour establishment and activity against pre-existing tumour (Mulryan et al, 2002). TroVax has been used clinically in phase I and II trials for patients with metastatic colorectal cancer and can induce antibody and $\mathrm{T}$-cell responses to 5T4 with no toxicity (Valle et al, 2003). This finding is of relevance to RCC as this is one of few diseases were positive clinical results have been observed using a vaccine-based approach. A recent German trial has demonstrated improved disease free-survival with an adjuvant tumour cell vaccine in high-risk RCC patients (Jocham et al, 2004).

Another approach utilising 5T4 involves generation of a monoclonal antibody immune conjugate. Here, a monoclonal antibody against 5T4 is linked to a superantigen such as Staphylococcal enterotoxin B that directly binds the T-cell receptor in a construct engineered to reduce its MHC class II binding. Thus, the fusion protein acquires the ability to activate $\mathrm{T}$ cells when binding to the 5T4 target on the tumour cell. Accumulation of this immune conjugate at the tumour site should then result in local T-cell recruitment and activation (Connolly et al, 2003).

It has been recognised that the $5 \mathrm{~T} 4$ antigen is present on a wide range of tumour types and that its expression can be associated with a poorer prognosis. In our study, we have insufficient numbers to correlate the degree of expression to prognosis or histological grade. Previous studies have shown that the human $5 \mathrm{~T} 4$ protein when transduced into cell lines reduces cell-cell contacts and enhances cell motility, suggesting it may play a role in supporting tumour invasion and metastasis (Carsberg et al, 1995, 1996). The remarkable finding in this study is the consistency of high expression levels of 5T4 in RCC and it is therefore tempting to speculate whether this may be linked to other proteins expressed to high levels in RCC. A frequent finding in the majority of conventional clear cell carcinomas is a mutation in the von Hippel-Lindau (VHL) suppressor gene (Ma et al, 2001), the protein product of this gene is required for degradation of hypoxiainducible factor $1 \alpha($ HIF- $1 \alpha)$. Tumour hypoxia and VHL gene mutations in RCC lead to accumulation of HIF-1 $\alpha$ (Wiesener et al, 2001 ), this protein then leads to transcription of a number of genes which predominantly affect angiogenesis and assist in tumour expansion. The human 5T4 promoter sequence has been examined and does not appear to contain any sequences that are now known to be HIF- $1 \alpha$ responsive (Myers et al, 1994), but this is an area which needs further exploration, particularly because HIF- $1 \alpha$ is instrumental in mediating early trophoblast differentiation. Our main interest in this protein, however, is that it represents a useful tumour antigen in that it is expressed strongly at the cell surface in RCC tumours and minimally in normal tissues. We did observe focal glomerular staining within surrounding kidney in one of the five patients from whom normal tissue could be obtained. We therefore propose that because of the consistent expression of this protein in RCC and the sensitivity of this tumour to immuno- logical therapies, future trials of 5T4-targeted agents could particularly focus on this population of cancer patients.

The use of adoptively transferred $\mathrm{T}$ cells as a therapy for solid tumours is still in its infancy, with one of the main barriers to the technique being the ability to generate large numbers of tumour antigen-specific lymphocytes. Large numbers of tumour reactive lymphocytes isolated from naturally occurring TIL populations have been used for the treatment of melanoma and clinical responses have been observed in patients who had already failed multiple lines of conventional therapy (Dudley et al, 2002). However, in one case report, resistance to treatment occurred as a result of the therapy selecting out tumour cells which lack MHC I expression (Khong et al, 2004). Isolation of tumour-specific clones of $\mathrm{T}$ cells is possible with melanoma because of common presence of skin metastases and identification of common T-cell antigens; obtaining and expanding such cells from other solid tumours has been more difficult. The ability to engineer $\mathrm{T}$ cells from the peripheral blood and confer on them antibodytype specificity without the need for MHC presentation of antigen by tumour represents an important step forward in bypassing some of the barriers to effective T-cell therapy. This modality is also likely to have a number of advantages over conventional monoclonal antibody therapy in that $\mathrm{T}$ cells have discrete homing and tissue penetration capabilities together with the ability to effect immediate target cell death on activation via their T-cell receptor. As a result of the potency of the T-cell response, one major concern is that of reactivity against normal host cells that also express the protein that is being targeted. Evidence to date suggests that 5T4 is expressed at low levels in normal subjects but a carefully planned phase I study is now appropriate.

Adoptive T-cell therapy is of particular relevance to RCC given the sensitivity of this tumour to immunomodulatory drugs. The ability to generate 5T4-specific $\mathrm{T}$ cells ex vivo represents an important advance in bringing this modality of treatment into the clinic. Before this technique is scaled up for clinical use, there remain issues yet to be resolved. Firstly, the 5T4.CD3 $\zeta$ construct has a comparatively poor transduction efficiency using the Kat retrovirus as described, and this needs to be optimised. Secondly, the optimal method of expanding $\mathrm{T}$ cells for transduction is still being debated. We routinely use IL-2 to expand T cells, but evidence is emerging that this may also assist in the expansion of regulatory $\mathrm{T}$ cells, this subpopulation may be impeding some of the observed cytotoxicity that we are engineering in to these cells (Nelson, 2004). There may be advantages in using different cytokines such as IL-7 and IL-15 to grow cytotoxic T cells (Antony and Restifo, 2005), or alternatively magnetically depleting regulatory cells from the precursor population. Another development in the field of T-cell expansion is the use of T-cell expansion beads coated with antibodies to CD2, CD3 and CD28 (Dudley, 2003). These appear to provide more reliable and rapid expansion of $\mathrm{T}$ cells and may therefore improve transduction efficiency and also generate higher numbers of cells that are needed for adoptive transfer.

In conclusion, we have shown that polyclonal lymphocytes taken from the peripheral blood can be directed against the 5T4 protein strongly expressed on the vast majority of RCCs. This method could lead to an effective approach for the cellular therapy of this notoriously difficult disease.

\section{ACKNOWLEDGEMENTS}

This work has been funded by a grant from Cancer Research UK. The renal cell carcinoma lines were donated by Dr James Yang of the National Institutes of Health, MD, USA. We also thank Garry Ashton for his assistance with the immunohistochemistry and Allison O'Neill for preparation of the retroviral constructs. 


\section{REFERENCES}

Antony PA, Restifo NP (2005) CD4+CD25+ T regulatory cells, immunotherapy of cancer, and interleukin-2. J Immunother 28(2): 120-128

Atzpodien J, Royston P, Wandert T, Reitz M, DGCIN - German Cooperative Renal Carcinoma Chemo-Immunotherapy Group (2003) Metastatic renal carcinoma comprehensive prognostic system. $\mathrm{Br} J$ Cancer 88: 348 -353, doi:10.1038/sj.bjc.6600768

Bleumer I, Knuth A, Oosterwijk E, Hofmann R, Varga Z, Lamers C, Kruit W, Melchior S, Mala C, Ullrich S, De Mulder P, Mulders PF, Beck J (2004) A phase II trial of chimeric monoclonal antibody G250 for advanced renal cell carcinoma patients. Br J Cancer 90(5): 985-990, doi:10.1038/ sj.bjc. 6601617

Cancer Registration Statistics (2001) Vol. 32. UK Office of National Statistics

Carsberg CJ, Myers KA, Evans GS, Allen TD, Stern PL (1995) Metastasisassociated 5T4 oncofoetal antigen is concentrated at microvillus projections of the plasma membrane. J Cell Sci 108: 2905-2916

Carsberg CJ, Myers KA, Stern PL (1996) Metastasis-associated 5T4 antigen disrupts cell - cell contacts and induces cellular motility in epithelial cells. Int J Cancer 68(1): 84-92

Clynes RA, Towers TL, Presta LG, Ravetch JV (2000) Inhibitory Fc receptors modulate in vivo cytoxicity against tumour targets. Nat Med 6: $443-446$

Cobleigh MA, Vogel CL, Tripathy D, Robert NJ, Scholl S, Fehrenbacher L, Wolter JM, Paton V, Shak S, Lieberman G, Slamon DJ (1999) Multinational study of the efficacy and safety of humanized anti-HER2 monoclonal antibody in women who have HER2-overexpressing metastatic breast cancer that has progressed after chemotherapy for metastatic disease. J Clin Oncol 17: 2639-2648

Connolly NB, Shaw DM, Patel PM, Garner CM, Beirne D, Kilany S, Gunnar H, Forsberg G, Stern P, Hawkins RE (2003) A phase II study of ABR214936 (anatumomab mafenatox) tumour targeted superantigen (TTS) therapy in patients with advanced renal cell carcinoma (RCC). Proc Am Soc Clin Oncol 22: 177

Czuczman MS, Weaver R, Alkuzweny B, Berlfein J, Grillo-Lopez AJ (2005) Prolonged clinical and molecular remission in patients with low-grade or follicular non-Hodgkin's lymphoma treated with rituximab plus CHOP chemotherapy: 9-year follow-up. J Clin Oncol 23(1): 248, DOI: 10.1200/ JCO.2004.04.020

Darcy PK, Haynes NM, Snook MB, Trapani JA, Cerruti L, Jane SM, Smyth MJ (2000) Redirected perforin-dependent lysis of colon carcinoma by ex vivo genetically engineered CTL. J Immunol 164: 3705-3712

Dillman R, Schiltz P, DePriest C, Barth N, Beutel L, de Leon C, O'Connor A Nayak S (2004) Tumour-infiltrating lymphocytes and interleukin-2: dose and schedules of administration in the treatment of metastatic cancer. Cancer Biother Radiopharm 19(6): $730-737$

Dudley M (2003) To bead or not to bead. J Immunother 6(3): 187-189

Dudley ME, Wunderlich JR, Robbins PF, Yang JC, Hwu P, Schwartzentruber DJ, Topalian SL, Sherry R, Restifo NP, Hubicki AM, Robinson MR Raffeld M, Duray P, Seipp CA, Rogers-Freezer L, Morton KE, Mavroukakis SA, White DE, Rosenberg SA (2002) Cancer regression and autoimmunity in patients after clonal repopulation with antitumour lymphocytes. Science 298(5594): 850-854

Figlin RA, Thompson JA, Bukowski RM, Vogelzang NJ, Novick AC, Lange P, Steinberg GD, Belldegrun AS (1999) Multicenter, randomized, phase III trial of $\mathrm{CD} 8(+)$ tumour-infiltrating lymphocytes in combination with recombinant interleukin-2 in metastatic renal cell carcinoma. J Clin Oncol 17(8): 2521-2529

Finer MH, Dull TJ, Qin L, Farson D, Roberts MR (1994) kat: a highefficiency retroviral transduction system for primary human $\mathrm{T}$ lymphocytes. Blood 83: $43-50$

Finn OJ, Lotze MT (2001) A decade in the life of tumour immunology. Clin Cancer Res 7(Suppl 3): 759s-760s

Garrido F, Ruiz-Cabello F, Cabrera T, Perez-Villar JJ, Lopez-Botet M, Duggan-Keen M, Stern PL (1997) Implications for immunosurveillance of altered HLA class I phenotypes in human tumours. Immunol Today 18: $89-95$

Gilham DE, O'Neill A, Hughes C, Guest RD, Kirillova N, Lehane M, Hawkins RE (2002) Primary polyclonal human t lymphocytes targeted to carcino-embryonic antigens and neural cell adhesion molecule tumour antigens by $\mathrm{CD} 3 z$-based chimeric immune receptors. J Immunother 25(2): $139-151$

Goedegebuure PS, Douville LM, Li H, Richmond GC, Schoof DD, Scavone M, Eberlein TJ (1995) Adoptive immunotherapy with tumour-infiltrating lymphocytes and interleukin-2 in patients with metastatic malignant melanoma and renal cell carcinoma: a pilot study. J Clin Oncol 13(8): $1939-1949$

Guest RD, Hawkins RE, Kirillova N, Cheadle EJ, Arnold J, O’Neill A, Irlam J, Chester KA, Kemshead J, Shaw D, Embleton J, Stern PL, Gilham DE (2005) The role of extracellular spacer regions in the optimal design of chimeric immune receptors: evaluation of four different scFvs and antigens. J Immunother 28(3): 203-211

Hole N, Stern PL (1988) A $72 \mathrm{kDa}$ trophoblast glycoprotein defined by a monoclonal antibody. $\mathrm{Br}$ J Cancer 57: $237-246$

Jain RK (1999) Transport of molecules, particles and cells in solid tumours. Ann Rev Bio Eng 1: 241 -263, doi:10.1146/annurev.bioeng.1.1.241

Jocham D, Richter A, Hoffmann L, Iwig K, Fahlenkamp D, Zakrzewski G, Schmitt E, Dannenberg T, Lehmacher W, von Wietersheim J, Doehn C (2004) Adjuvant autologous renal tumour cell vaccine and risk of tumour progression in patients with renal-cell carcinoma after radical nephrectomy: phase III, randomised controlled trial. Lancet 363 594-599

Khong HT, Wang QT, Rosenber SA (2004) Identification of multiple antigens recognized by tumour-infiltrating lymphocytes from a single patient: tumour escape by antigen loss and loss of MHC expression. J Immunother 27(3): 184-190

Lamers CH, Willemsen RA, Luider BA, Debets R, Bolhuis RL (2002) Protocol for gene transduction and expansion of human $\mathrm{T}$ lymphocytes for clinical immunogene therapy of cancer. Cancer Gene Ther 9(7): $613-623$

Le X, McWatters A, Wiener J, Wu J, Mills GB, Bast RC (2000) Anti-HER2 antibody and heregulin suppress growth of HER2-overexpressing human breast cancer cells through different mechanisms. Clin Cancer Res 6: $260-270$

Ma X, Yang K, Lindblad P, Egevad L, Hemminki K (2001) VHL gene alterations in renal cell carcinoma patients: novel hotspots or founder mutations and linkage disequilibrium. Oncogene 20: 5393-5400

Mapara YM, Sykes M (2004) Tolerance and cancer: mechanisms of tumour evasion and strategies for breaking tolerance. J Clin Oncol 22(6): 1136 - 1151, DOI: 10.1200/JCO.2004.10.041

MRC Renal Cancer Collaborators (1999) Interferon-alpha and survival in metastatic renal carcinoma: early results of a randomised controlled trial. Lancet 353: $14-17$

Mulryan K, Ryan MG, Myers KA, Shaw D, Wang W, Kingsman SM, Stern PL, Carroll MW (2002) Attenuated recombinant vaccinia virus expressing oncofoetal antigen (tumour-associated antigen) 5T4 induces active therapy of established tumours. Mol Cancer Ther 1: 1129-1137

Myers KA, Rahi-Saund V, Davison MD, Young JA, Cheater AJ, Stern PL (1994) Isolation of a cDNA encoding 5T4 oncofetal trophoblast glycoprotein. An antigen associated with metastasis contains leucinerich repeats. J Biol Chem 269(12): 9319-9324

Nelson BH (2004) IL-2, regulatory T-cells and tolerance. J Immunol 172(7): $3983-3988$

Oosterwijk E, Ruiter DJ, Hoedemaeker PJ, Pauwels EK, Jonas U, Zwartendijk J, Warnaar SO (1986) Monoclonal antibody G 250 recognizes a determinant present in renal-cell carcinoma and absent from normal kidney. Int J Cancer 38(4): 489-494

Reilly RM, Sandhu J, Alvarez-Diez TM, Gallinger S, Kirsh J, Stern H (1995) Problems of delivery of monoclonal antibodies: pharmaceutical and pharmacokinetic solutions. Clin Pharmacokinet 28: 126-142

Sheen AJ, Irlam J, Kirillova N, Guest RD, Sherlock DJ, Hawkins RE, Gilham DE (2003) Gene therapy of patient-derived T lymphocytes to target and eradicate colorectal hepatic metastases. Dis Colon Rectum 46(6): $793-804$

Southall PJ, Boxer GM, Bagshaw KD, Hole N, Bromley M, Stern PL (1990) Immunological distribution of $5 \mathrm{~T} 4$ antigen in normal and malignan tissues. Br J Cancer 61: 89-95

Starzynska T, Marsh PJ, Schofield PF, Roberts SA, Myers KA, Stern PL (1994) Prognostic significance of 5T4 oncofoetal antigen expression in colorectal carcinoma. Br J Cancer 69: 899-902

Thistlethwaite F, Mansoor W, Gilham DE, Hawkins RE (2005) Engineering T-cells with antibody-based chimeric receptors for effective cancer therapy. Curr Opin Mol Ther 7(1): 48-55

Valle JW, Connolly NB, Harrop R, McNeill H, Garner CM, Fenemore J, Saunders MP, Kingsman S, Carroll MW, Hawkins RE (2003) Phase I study of escalating doses of TroVax in patients with advanced colorectal cancer. Proc Am Soc Clin Oncol 22: 181 
Wiesener MS, Munchenhagen PM, Berger I, Morgan NV, Roigas J, Schwiertz A, Jurgensen JS, Gruber G, Maxwell PH, Loning SA, Frei U, Maher ER, Grone HJ, Eckardt KU (2001) Constitutive activation of hypoxia-inducible genes related to overexpression of hypoxia-inducible factor-1alpha in clear cell renal carcinomas. Cancer Res 61(13): 52155222

Wiseman GA, Gordon LI, Multani PS, Witzig TE, Spies S, Bartlett NL, Schilder RJ, Murray JL, Saleh M, Allen RS, Grillo-Lopez AJ, White CA
(2002) Ibritumomab tiuxetan radioimmunotherapy for patients with relapsed or refractory non-Hodgkin's lymphoma and mild thrombocytopenia: a phase II multicenter trial. Blood 99: 4336-4342

Yang JC, Sherry RM, Steinberg SM, Topalian SL, Schwartzentruber DJ, Hwu P, Seipp CA, Rogers-Freezer L, Morton KE, White DE, Liewehr DJ, Merino MJ, Rosenberg SA (2003) Randomized study of high-dose and low-dose interleukin-2 in patients with metastatic renal cancer. J Clin Oncol 21(16): 3127-3132 